\title{
PEMBERIAN HORMAX DAN NPK MUTIARA 16:16:16 PADA TANAMAN UBI JALAR ( Ipomoea batatas L.)
}

\section{Giving of Hormax and NPK Mutiara (16:16:16) on Sweet Potato Plants (Ipomoea batatas L.)}

\author{
Budiman Manurung, Siti Zahrah, Zulkifli \\ Program Studi Agroteknologi, Fakultas Pertanian Universitas Islam Riau \\ J1. Khaharuddin Nasution No.113 Pekanbaru. 28284 \\ Telp: 0761-674681; Fax: 0761-674681 \\ [Diterima: Mei 2018; Disetujui; Agustus 2018)
}

\begin{abstract}
The purpose of this study was to determine the effect of Hormax and NPK Mutiara (16:16:16) on sweet potato plants. The design used in this study was a Factorial Complete Randomized Design consisting of two factors. The first factor is $\operatorname{Hormax}(\mathrm{H})$ at doses of $0,1,3$, and $5 \mathrm{ml}$ per liter of water while the second factor is NPK Mutiara $(16: 16: 16)(\mathrm{N})$ with concentrations of $0,3.15,6.3$, and $9.45 \mathrm{~g}$ per plant. The parameters observed were the number of crop tubers (tubers), tuber weight per plot $(\mathrm{g})$, tuber weight per tuber $(\mathrm{g})$, tuber weight per plant $(\mathrm{g})$, wet pruned weight $(\mathrm{g})$, harvest index. The last observation data were analyzed statistically and continued with a BNJ follow-up test at the 5\% level. The results showed that the interaction of giving Hormax and NPK Mutiara (16:16:16) significantly affected the number of tubers per plant, tuber weight per plot, tuber weight per fruit, weight. The best treatment is in the combination of H2N2 fertilizer concentration of $3 \mathrm{ml} / \mathrm{liter}$ of water and $6.3 \mathrm{~g} /$ plant. The main influence of hormax is evident on the parameters of the number of tubers per plant, tuber weight per plot, tuber weight per tuber, tuber weight per plant, wet perched weight, harvest index, the best treatment of $3 \mathrm{ml}$ per liter of water $(\mathrm{H} 2)$. The main effect of NPK Mutiara fertilizer (16:16:16) is real on the parameters of the number of tubers per plant, tuber weight per plot, tuber weight per fruit, tuber weight per plant, wet perched weight, harvest index, best treatment ie 6.3 g per plants $(\mathrm{N} 2)$.
\end{abstract}

Keywords: Hormax, NPK, Sweet Potatoes

\begin{abstract}
ABSTRAK
Tujuan penelitian untuk mengetahui pengaruh pemberian Hormax dan NPK Mutiara (16:16:16) pada tanaman ubi. Rancangan yang digunakan dalam penelitian ini adalah Rancangan Acak Lengkap Faktorial yang terdiri dari dua faktor. Faktor pertama adalah Hormax $(\mathrm{H})$ dengan dosis $0,1,3$, dan $5 \mathrm{ml}$ per liter air sedangkan faktor kedua yaitu NPK Mutiara (16:16:16) (N) dengan konsentrasi 0, 3,15, 6,3, dan 9,45g per tanaman. Parameter yang di amati adalah jumlah umbi pertanaman (umbi), berat umbi per plot (g), berat umbi per umbi (g), berat umbi pertanaman (g), berat berangkasan basah (g), indeks panen . Data pengamatan terakhir dianalisis secara statistik dan dilanjutkan dengan uji lanjut BNJ pada taraf 5\%. Hasil penelitian menunjukkan bahwa interaksi pemberian Hormax dan NPK Mutiara (16:16:16) berpengaruh nyata terhadap jumlah umbi per tanaman, berat umbi per plot, berat umbi per buah, berat berangkas basah. Perlakuan terbaik terdapat pada kombinasi perlakuan pupuk H2N2 konsentrasi $3 \mathrm{ml} / \mathrm{liter}$ air dan 6,3 g/tanaman. Pengaruh utama hormax nyata terhadap parameter jumlah umbi per tanaman, berat umbi per plot, berat umbi per umbi, berat umbi per tanaman, berat berangkas basah,indeks panen, Perlakuan terbaik $3 \mathrm{ml}$ per liter air (H2) . Pengaruh utamapupuk NPK Mutiara (16:16:16) nyata terhadap parameter jumlah umbi per tanaman, berat umbi per plot, berat umbi per buah, berat umbi per tanaman, berat berangkas basah,indeks panen, perlakuan terbaik yakni 6,3 g per tanaman (N2).
\end{abstract}

Kata kunci: Hormax, NPK, Ubi Jalar 


\section{PENDAHULUAN}

Ubi jalar (Ipomoea batatas. L) termasuk dalam suku kangkung-kangkungan (Convolvulaceae) dengan sifat batangnya yang menjalar. Tanaman ini banyak di tanam untuk dimanfaatkan umbinya, karena umbi jalar merupakan sumber karbohidrat yang sudah lama dikenal oleh masyarakat Indonesia. Selain karbohidrat, ubijalar juga mengandung vitamin A, C, mineral dan antosianin yang sangat bermanfaat bagi kesehatan,. disamping itu, ubi jalar tidak hanya digunakan sebagai bahan pangan tetapi juga sebagai bahan baku industri dan pakan ternak. Sedangkan di Irian Jaya, ubi jalar digunakan sebagai makanan pokok (Rahayuningsih, 2012).

Tanaman ubi jalar di indonesia sangat penting, baik sebagai makanan pokok alternatif di musim paceklik maupun makanan tambahan dalam rangka diversifikasi makanan. Komposisi ubi jalar per $100 \mathrm{~g}$ bahan adalah air $70 \mathrm{~g}$, serat $0,3 \mathrm{~g}$, kalori $113 \mathrm{kal}$, protein 2,3 g, besi 1,0 g, kalsium $46 \mathrm{mg}$, vitamin A 7,10 iu, vitamin $\mathrm{B}_{1}$ $0,08 \mathrm{mg}$, vitamin $\mathrm{B}_{2} 0,05 \mathrm{mg}$, niasin $0,9 \mathrm{mg}$, vitamin C 2,0 mg, pati $17,4 \%$ basah dan karaton 2,80 mg. Oleh karena itu ubi jalar memegang peran penting bagi para petani itu sendiri maupun orang lain yang mengkomsumsinya dan dalam ketahanan pangan untuk masyarakat itu sendiri (Andrianto dan Indarto,2014).

Berdasarkan Badan Pusat Statistik Riau (2017) pada tahun 2014 luas panen ubi jalarmencapai 981 ha dengan produksi tanaman ubi jalar mencapai 8.038 ton, kemudian pada tahun 2015 produksi tanaman ubi jalar mengalami penurunan yaitu 6.562 ton dengan luas lahan 793 ha, Berdasarkan data diatas, produksi ubi jalar masih tergolong rendah (BPS, 2017)

Salah satu upaya untuk meningkatkan produksi ubi jalar dapat dilakukan dengan cara penggunaan bibit unggul, pengolahan tanah yang baik dan penyediaan unsur hara dalam tanah. Usaha yang dilakukan dalam penyediaan unsur hara untuk meningkatkan hasil ubi jalar dapat ditempuh dengan cara pemupukan. Pemupukan merupakan salah satu aspek agronomis yang penting diperhatikan karena berhubungan erat dengan medium tanam. Tanah sebagai medium tumbuh yang menyediakan unsur hara bagi tanaman, perbaikan tersebut dapat dilakukan dengan pemberian Hormax dan NPK Mutiara (16:16:16).

Hormon atau zat pengatur tumbuh pada tanaman adalah senyawa organik bukan hara, yang jumlah sedikit dapat mendukung, menghambat dan dapat merubah proses fisiologi tumbuhan, Ada tiga hormon mutlak dibututhkan oleh tanaman dalam proses pertumbuhannya, yaitu: Auksin, Giberelin, dan Sitokinin. Apabila tanaman kekurangan salah satu hormon tersebut maka pertumbuhannya akan terganggu, hormon yang terkandung dalam hormon organik terdiri dari auksin, giberelin dan sitokinin. Salah satu produk yang menyajikan Hormon organik adalah Hormax (Anonimus, 2014).

Pemanfaatan hormon untuk memperbaiki pertumbuhan ubi jalar merupakan salah satu teknologi yang dapat dipilih untuk diterapkan. Pemanfaatan hormon tertentunya sangat bermanfaat dalam mendukung pertanian ramah lingkungan, pemanfaatan sumber daya alam dan peningkatan percepatan swasembada. Umumnya kandungan senyawa organik yang terkandung dalam bahan organik seperti hormax sangat baik bila dibandingkan dengan pupuk organik lainya, untuk mendapatkan pertumbuhan yang lebih baik perlu dipacu dengan pemberian pupuk NPK Mutiara (16:16:16), selain itu pemberian Hormax dapat mengurangi penggunaan pupuk NPK Mutiara (16:16:16). Penggunaan pupuk majemuk NPK Mutira (16:16:16) yang diberikan kedalam tanah dapat memberikan keuntungan dalam penghematan tenaga kerja dan juga dapat memberikan 3 jenis unsur hara dalam sekali pemberian.

Peranan utama nitrogen $(\mathrm{N})$ membantu pertumbuhan tanaman secara keseluruhan (vegetatif) membantu pembentukan zat hijau daun yang berguna untuk proses fotosintesis serta pembentukan protein, lemak dan senyawa organik lainya. Peran utama(P) untuk transper energi dalam sel tanaman misalnya ADP dan ATP, membantu pertumbuhan akar tanaman muda, bahan mentah pembentukan protein dan meningkatkan efesiensi fungsi dan penggunaan N. Peran utama kalium (K) memperkuat jaringan tanaman agar berbunga, daun tidak mudah gugur, merupakan komponen mengatur osmotik dalam sel, membantu memacu 
translokasi pembentukan protein karbohidrat keorgan tanaman lain serta merupakan kekuatan bagi tanaman menghadapi kekeringan dan penyakit.

Berdasarkan permasalahan diatas penulis tertarik melakukan penelitian dengan judul "Pemberian Hormax dan NPK Mutiara 16:16:16 Pada Tanaman Ubi Jalar (Ipomoea batatas. L).

\section{BAHAN DAN METODE}

Penelitian ini dilaksanakan di lahan percobaan Fakultas Pertanian Universitas Islam Riau Pekanbaru, Jalan Kaharudin Nasution,KM 11, No. 113, Kelurahan Air Dingin, Kecamatan Bukit Raya, Kota Pekanbaru. Penelitian ini dilaksanakan selama 4 bulan terhitung dari bulan Juli sampai Oktober 2017

Bahan yangdigunakan dalam penelitian ini adalah: setek ubi jalar varietas Mendut. Pupuk kandang, pupuk Hormax, Pupuk NPK Mutiara 16:16:16, Decis 25 EC, Regent 35 SC, Dithane M-45, Furadan 3G, Paku dan seng. Sedangkan alat-alat yang akan digunakan antara lain yaitu: parang, cangkul, garu, gunting setek, sprayer, gembor, meteran, gelas ukur $250 \mathrm{ml}$, timbangan, seng, palu, paku, ember, cat, spidol, patok, tali rafia, alat-alat tulis dan kamera.
Penelitian ini menggunakan Rancangan Acak Lengkap (RAL) secara faktorial yang terdiri dari dua faktor. Faktor pertama adalah Hormax $(\mathrm{H})$ yang terdiri dari 4 tarafdan faktor kedua adalah NPK Mutiara 16:16:16 (N) yang terdiri dari 4 taraf sehingga percobaan ini terdiri dari 16 kombinasi perlakuan. setiap kombinasi perlakuan diulang $3 \mathrm{kali}$, sehingga diperoleh 48 satuan percobaan, dimana setiap ulangan terdiri 4 tanaman, 2 tanaman dijadikan sampel, jumlah tanaman seluruhnya 192 tanaman. Dari hasil pengamatan masing-masing perlakuan dianalisa secara statistik. Apabila F hitung lebih besar dari $\mathrm{F}$ tabel maka dilanjutkan dengan uji lanjut beda nyata jujur (BNJ) pada taraf $5 \%$.

\section{HASIL DAN PEMBAHASAN}

\section{Jumlah Umbi per tanaman (Umbi)}

Hasil pengamatan terhadap jumlah umbi pertanaman setelah dianalisis ragam menunjukkan bahwa interaksi perlakuan pupuk Hormax dan NPK Mutiara 16:16:16 menberikan pengaruh yang nyata terhadap jumlah umbi pertanaman. Rerata hasil pengamatan jumlah per tanaman setelah di uji lanjut BNJ pada taraf 5\% dapat dilihat pada Tabel 1.

Tabel 1. Rerata jumlah umbi per tanaman dengan pemberian pupuk Hormax dan NPK Mutiara $16: 16: 16$ (buah)

\begin{tabular}{|c|c|c|c|c|c|}
\hline \multirow{2}{*}{$\begin{array}{l}\text { Pemberian Hormax } \\
\text { (ml/liter air) }\end{array}$} & \multicolumn{4}{|c|}{ Pupuk NPK Mutiara 16:16:16 (g/tanaman) } & \multirow[b]{2}{*}{ Rerata } \\
\hline & N0 (0) & N1 $(3,15)$ & $\mathrm{N} 2(6,3)$ & N3 $(9,45)$ & \\
\hline $\mathrm{H} 0(0)$ & $2,33 \mathrm{n}$ & $3,08 \mathrm{~g}-\mathrm{n}$ & $3,48 \mathrm{f}-\mathrm{k}$ & $3,38 \mathrm{f}-\mathrm{m}$ & $3,07 \mathrm{~d}$ \\
\hline H1 (1) & 2,78 k-n & $3,67 \mathrm{fhg}$ & $4,67 \mathrm{a}-\mathrm{d}$ & $3,57 \mathrm{f}-\mathrm{j}$ & $3,67 \mathrm{c}$ \\
\hline $\mathrm{H} 2(3)$ & $3,43 \mathrm{f}-1$ & 4,58a-e & $5,00 \mathrm{a}$ & $4,80 \mathrm{abc}$ & $4,45 \mathrm{a}$ \\
\hline $\mathrm{H} 3(5)$ & $3,62 \mathrm{f}-\mathrm{i}$ & $3,83 \mathrm{fg}$ & $4,82 \mathrm{ab}$ & $4,10 \mathrm{~b}-\mathrm{f}$ & $4,09 \mathrm{~b}$ \\
\hline Rerata & $3,04 \mathrm{~d}$ & $3,79 \mathrm{c}$ & $4,49 \mathrm{a}$ & $3,96 \mathrm{~b}$ & \\
\hline
\end{tabular}

Angka-angka pada baris kolom yang diikuti oleh huruf kecil yang sama tidak berbeda nyata berdasarkan Uji BNJ taraf 5\%.

Data pada Tabel 1 memperlihatkanbahwa interaksi pemberian Pupuk Hormax dan NPK Mutiara (16:16:16)berpengaruh nyata terhadap jumlah umbi pertanaman,dimana secara interaksi kombinasi perlakuan Hormax 3 ml/liter air dan NPK Mutiara(16:16:16) 6,3 $\mathrm{g} / \operatorname{tanamanH} 2 \mathrm{~N} 2$, mencapai 5,00 umbi, tidak berbeda nyata dengan perlakuan
H3N2,H2N3,H1N2,H2N1 berbeda nyata dengan perlakuan lainya.

Perlakuan yang menunjukkan rerata jumlah umbi pertanaman tertinggi di bandingkan dengan perlakuan lainya adalah Pupuk Hormax $3 \mathrm{ml} /$ liter air dan NPK Mutiara (16:16:16) 6,3 g/tanaman (H2N2) yaitu 5,00 umbi. Hal ini diduga karena kombinasi Pupuk Hormax dan NPK Mutiara 16:16:16 mampu menyediakan unsur hara kalium tanaman 
dengan baik dan sesuai yang menyebabkan pertumbuhan dan perkembangan perakaran tanaman ubi jalar yang maksimal, translokasi kerbohidrat dari daun ke akar, pembentukan karbohidrat, protein dan gula sebagai pembentuk cadangan makanan menjadi berlangsung dengan baik sehingga umbi yang terbentuk menjadi tinggi.

Data pada Tabel 1 memperlihatkan bahwa pengaruh utama pemberian Hormaxberpengaruh nyata terhadap jumlah umbi per tanaman, dimana perlakuan $\mathrm{H} 2$ (3 $\mathrm{ml} /$ liter air) memiliki jumlah umbi per tanaman mencapai 4,45 umbi. Perlakuan H2 berbeda nyata dengan perlakuan lainya. Pemberian Hormax dapat memberikan pengaruh besar pada tanah yang bisa bermanfaat untuk merangsang pertumbuhan akar, batang daun dan bunga. Hal ini karena adanya kadar haranya yang tepat untuk kebutuhan tanaman dan pengunaanya lebih efektif dan efisien.

Hormax tidak hanya mampu menyediakan unsur hara tetapi juga dapat: 1) mengandung hormon atau zat perangsang tumbuh organik terlengkap. 2) merangsang percepatan keluarnya akar, perbanyakan akar dan mata akar. 3) merangsang proses pertumbuhan dengan cara pembelahan sel, memperbesar ukuran sel dan jaringan sel. 4) merangsang keluarnya bunga dan buah secara serentak. 5) merangsang proses penyembuhan dari luka petik atau luka gigitan hama dan penyakit. 6) merangsang pembesaran pada rimpang dan umbi-umbian dengan ekstra cepat dan ekstra besar. Hal ini menyebabkan pertumbuhan dan perkembangan dan perkembangan akar menjadi tinggi, jumlah akar yang tinggi tersebut berperan dalam peningkatan pembentukan umbi menjadi semakin tinggi karena umbi terbentuk dari proses diferensiasi akar sebagai tempat penyimpanan cadangan makanan. Hal ini juga yang terjadi pada perlakuan $\mathrm{H} 2 \mathrm{~N} 2(3 \mathrm{ml} / \mathrm{liter}$ air dan 6,3 g/tanaman), karena kombinasi dosis pemberian Pupuk Hormax dan NPK Mutiara 16:16:16 mampu menyediakan unsur hara $\mathrm{K}$ dengan baik dan seimbangan.

Hasil penelitian Ralahalu (2013) menyimpulkan bahwa pemberian ZPT Hormax memberikan pengaruh terhadap pertumbuhan dan produksi cabai (Capsicum annuum L.) konsentrasi $3 \mathrm{ml} /$ liter air, memberikan hasil lebih tinggi dibandingkan perlakuan lainnya terhadap tinggi tanaman, jumlah cabang, jumlah bunga, jumlah buah panen dan berat buah panen. Hasil penelitian Nurahmi (2010) menunjukkan bahwa pemberian konsentrasi pupuk organik cair NASA (4 cc/liter air) dan zat pengatur tumbuh hormonik (2 cc/liter air) merupakan konsentrasi yang lebih untuk mendapatkan kualitas dan kuantitas berat barangkasan dan berat bunga tanaman.

Data pada Tabel 1 memperlihatkan bahwa pengaruh utama pemberian pupuk NPK Mutiara (16:16:16) berpengaruh nyata terhadap jumlah umbi per tanaman, dimana perlakuan $\mathrm{N} 2(6,3 \mathrm{~g} /$ tanaman) memiliki jumlah umbi per tanaman mencapai 4,49 umbi. Perlakuan N2 berbeda nyata dengan perlakuan lainya. Ini di sebabkan pada perlakuan N2 merupakan dosis yang tepat sehingga jumlah umbi per tanaman optimal. Apabila diberikan terlalu banyak akan menyebabkan larutan tanah akan pekat sehingga dapat menghambat pertumbuhan tanaman. Sebaliknya jika di berikan terlalu sedikit maka pengaruh pemupukan tidak akan tampak.

Marsono dan Sigit (2002), mengemukakan bahwa kekurangan unsur hara nitrogen pada tanaman dapat menyebabkan pertumbuhan tanaman lambat atau kecil, dan hijau kekuningan, daun sempit, pendek dan tegak daun tua cepat menguning dan mati. Sedangkan kekurangan unsur hara fosfor pada tanaman dapat menyebabkan daun berubah menjadi warna tua atau tampak kemerahan, tepi daun cabang dan batang bewarna ungu lalu berubah menjadi kuning, buah kecil dan lekas matang. Selain unsur fosfor, unsur kalium pada tanaman juga berperan penting dalam membantu pembentukan protein dan karbohidrat, memperkuat jaringan tanaman, membentuk anti bodi tanaman terhadap penyakit serta kekeringan dan mengaktifkan kerja beberapa enzim serta memacu translokasi karbohidrat dari daun keorgan tanaman yang lain.

Dalam penelitian Indrawati (2014), mengemukakan bahwa pemberian pupuk NPK Mutiara terhadap Ubi Jalar berpengaruh nyata terhadap parameter jumlah umbi pertanaman, bobot umbi per umbi dan berat umbi pertanaman, perlakuan terbaik pada pemberian NPK 20,2 g/tanaman atau setara dengan 300 $\mathrm{kg} / \mathrm{ha}$ pada tanaman ubi jalar. 


\section{Berat Umbi Per Plot (g)}

Hasil pengamatan berat umbi per plot pada tanaman ubi jalar, setelah dilakukan sidik ragam menunjukkan bahwa interaksi perlakuan Pupuk Hormax dan NPK Mutiara 16:16:16 menberikan pengaruh yang nyata terhadap jumlah umbi pertanaman. Rerata hasil pengamatan jumlah per tanaman setelah di uji lanjut $\mathrm{BNJ}$ pada taraf $5 \%$ dapat dilihat pada Tabel 2.

Tabel 2. Rerata berat umbi per plot pemberian Hormax dan NPK Mutiara 16:16:16 (g)

\begin{tabular}{|c|c|c|c|c|c|}
\hline \multirow{2}{*}{$\begin{array}{l}\text { Pemberian Hormax } \\
\text { (ml/liter air) }\end{array}$} & \multicolumn{4}{|c|}{ Pupuk NPK Mutiara 16:16:16 (g/tanaman) } & \multirow{2}{*}{ Rerata } \\
\hline & N0 (0) & N1 $(3,15)$ & N2 $(6,3)$ & N3 $(9,45)$ & \\
\hline H0 (0) & 513,33 o & $966,67 \mathrm{n}$ & $2103,33 \mathrm{jk}$ & $1526,67 \mathrm{~lm}$ & $1277,5 \mathrm{~d}$ \\
\hline H1 (1) & 770,00 no & 2663,33 fgh & $3110,00 a-d$ & $2316,67 \mathrm{hij}$ & $2215,00 \mathrm{c}$ \\
\hline $\mathrm{H} 2(3)$ & $1841,67 \mathrm{kl}$ & 3053,33 a-e & $3200,00 \mathrm{a}$ & $3156,67 \mathrm{abc}$ & 2812,92 a \\
\hline H3 (5) & $2528,33 \mathrm{f}-\mathrm{i}$ & $2716,67 \mathrm{efg}$ & $3178,33 \mathrm{ab}$ & $2813,33 \mathrm{~b}-\mathrm{f}$ & $2809,17 \mathrm{~b}$ \\
\hline Rerata & $1413,33 \mathrm{~d}$ & $2350,00 \mathrm{c}$ & $2897,92 \mathrm{a}$ & $2453,33 \mathrm{~b}$ & \\
\hline
\end{tabular}

Angka-angka pada baris kolom yang diikuti oleh huruf kecil yang sama tidak berbeda nyata berdasrkan Uji BNJ taraf 5\%.

Data pada Tabel 2 memperlihatkan bahwa interaksi pemberian Hormax dan NPK Mutiara 16:16:16berpengaruh nyata terhadap berat umbi jalar per plot, dimana pemberian Hormax3 ml/liter air dan NPK Mutiara 16:16:16 6,3 g/tanaman (H2N2) merupakan kombinasi perlakuan terbaik yang menghasilkan berat umbi 3200,00 g/plot, tidak berbeda nyata dengan kombinasi perlakuan $\mathrm{H} 3 \mathrm{~N} 2, \mathrm{H} 2 \mathrm{~N} 3, \mathrm{H} 1 \mathrm{~N} 2, \mathrm{H} 2 \mathrm{~N} 1$ dan berbeda nyata dengan perlakuan lainya.

Perlakuan terbaik Berat umbi per plot yang di hasilkan oleh kombinasi perlakuan (H2N2), hal ini di duga karena tingkat pemenuhan unsur hara dan mengandung hormon atau zat perangsang tumbuh organik terlengkap, merangsang percepatan keluarnya akar, perbanyakan akar dan mata akar, merangsang proses pertumbuhan dengan cara pembelahan sel, memperbesar ukuran sel dan jaringan sel, merangsang keluarnya bunga dan buah secara serentak, merangsang proses penyembuhan dari luka petik atau luka gigitan hama dan penyakit, merangsang pembesaran pada rimpang dan umbi-umbian dengan ekstra cepat dan ekstra besar dengan pemberian Hormax sebagai sudsitusi terbatas dan NPK Mutiara lebi mampu mempengaruhi terjadinya peningkatan proses fotosintesis dan distribusi hasil fotosintesis secara maksimal.

Data pada Tabel 2 memperlihatkan bahwa pengaruh utama pemberian Hormax berpengaruh nyata terhadap berat umbi per plot dengan perlakuan terbaik $\mathrm{H} 2$ ( $3 \mathrm{ml} / \mathrm{liter}$ air) dengan berat umbi per plot 2812,92 g/plot. berbeda nyata dengan perlakuan lainya. Adanya kandungan auksin, giberelin dan sitokinin yang memberikan sumber hara bagi tanaman ubi jalar, sehingga sangat membantu pertumbuhan generatif pada tanaman.

Kandungan yang dimiliki oleh ZPT Hormax yang bersifat positif terhadap pertumbuhan tanaman karena mengandung hormon golongan auksin, giberelin, dan sitokinin yang memberikan sumber harabagi tanaman ubi jalar. Pemberian Hormax berpengaruh terhadap berat umbi per plot, karena Hormax dapat merangsang percepatan keluarnya akar, perbanyakan serabuk akar dan mata akar, merangsang proses pertumbuhan melalui cara membelah sel, memperbesar ukuran sel dan jaringan, merangsang keluarnya bunga dan buah secara serentak, merangsang proses penyembuhan dari luka petik atau luka gigitan hama penyakit, dan merangsang pembesaran pada umbi-umbi dengan ekstra besar, sehingga tanaman ubi jalar dapat tumbuh dengan baik dan menadapatkan hasil produksi yang maksimal

Agregat-agregat tanah yang gembur, aerase dab draenase baik, tingkat kemasaman ideal dantingginya kandungan bahan organik serta ketersediaan unsur hara akan lebih mampu meningkatkan kualitas dan kuantitas hasil produksi tanaman (Nugroho, 2004). Hanafi (2005), menyatakan bahwa nusur hara yang 
tersedia dalam media tanam mampu diserap oleh tanaman dengan jumlah yang tepat dab seimbang mampu meningkatkan pembentukan buah, akibatnya dengan jumlah yang tepat dan seimbang mampu meningkatkan pembentukan buah, akibat dengan jumlah buah dan berat buah yang tinggi akan memberikan hasil produksi yang tinggi.

Data pada Tabel 2 memperlihatkan bahwa pemberian pupuk NPK Mutiara $(16 ; 16: 16)$ berpengaruh nyata terhadap berat umbi per plot, dimana perlakuan (N2) 6,3 g/tanaman memiliki berat umbi per plot 2897,92 g/plot,berbeda nyata dengan perlakuanlainya. Ini disebabkan pada perlakuan (N2) merupakan dosis yang tepat sehingga pertumbuhan generatif tanaman ubi jalar optimal.

Menurut hanafi (2005), pengaruh sinergis antara pupuk organik dan pupuk an-organik dapat meningkatkan efektifitas penyadiaan dan penguraian unsur hara, namun didalam konteks pengaruhnya terhadap pertumbuhan dan produksi tanaman dapat memberikan pengaruh yang berbeda dan saling berlawanan karena pupuk tersebut memiliki fungsi yang berbeda.
Arifin dan Nur Hayati (2005), mengemukakan bahwa untuk mendapatkan pertumbuhan tanaman yang baik, unsur hara esensial harus mencukupi, bila tanaman kekurungan unsur hara tanaman tanaman tidak akan melakukan fungsi fisiologisnya dengan baik dan akan berpengaruh terhadap tanaman yang dibudidayakan. Agustina (2004) mengemukakan bahwa unsur nitrogen, fosgor dan kalium sangat penting bagi tanaman, termasuk bagian yang berhubungan dengan perkembangan generatif yang menyebebkan metabolisme dalam tubuh tanaman menjadi lebih baik.

\section{Berat Umbi per Umbi (g)}

Hasil pengamatan berat umbi per umbi pada tanaman ubi jalar, setelah dilakukan sidik ragam menunjukkan bahwa interaksi perlakuan Pupuk Hormax dan NPK Mutiara 16:16:16 menberikan pengaruh yang nyata terhadap jumlah umbi pertanaman. Rerata hasil pengamatan jumlah per tanaman setelah di uji lanjut BNJ pada taraf 5\% dapat dilihat pada Tabel 3.

Tabel 3. Rerata berat umbi per umbi pemberian Hormax dan NPK Mutiara 16:16:16 (g)

\begin{tabular}{|c|c|c|c|c|c|}
\hline \multirow{2}{*}{$\begin{array}{l}\text { Pemberian Hormax } \\
\text { (ml//liter air) }\end{array}$} & \multicolumn{4}{|c|}{ Pupuk NPK Mutiara 16:16:16 (g/tanaman) } & \multirow[b]{2}{*}{ Rerata } \\
\hline & No $(0)$ & N1 $(3,15)$ & $\mathrm{N} 2(6,3)$ & N3 $(9,45)$ & \\
\hline $\mathrm{H} 0(0)$ & $128,33 \mathrm{n}$ & $146,07 \mathrm{mn}$ & $193,97 \mathrm{~h}-\mathrm{k}$ & $165,20 \mathrm{klm}$ & $158,39 \mathrm{~d}$ \\
\hline H1 (1) & $136,19 \mathrm{mn}$ & 225,30 e-h & $260,98 \mathrm{bcd}$ & $202,77 \mathrm{~g}-\mathrm{j}$ & $206,31 \mathrm{c}$ \\
\hline $\mathrm{H} 2(3)$ & $187,50 \mathrm{i}-1$ & 248,93 b-e & $300,00 \mathrm{a}$ & $277,17 \mathrm{abc}$ & $256,40 \mathrm{a}$ \\
\hline H3 (5) & $505,72 \mathrm{ghi}$ & $229,83 \mathrm{~d}-\mathrm{g}$ & $279,77 \mathrm{ab}$ & 242,65 def & $239,49 \mathrm{~b}$ \\
\hline Rerata & $164,44 \mathrm{~d}$ & $212,53 \mathrm{c}$ & $258,68 \mathrm{a}$ & $221,95 \mathrm{~b}$ & \\
\hline $\mathrm{KK}=5,15 \%$ & $\mathrm{BN}$ & $=33,62$ & BNJ H dan $\mathrm{N}$ & 12,25 & \\
\hline
\end{tabular}

Data padaTabel 3 Menunjukkan bahwa interaksi pemberian hormax dan NPK Mutiara (16:16:16) memberikan pengaruh terhadap pengamatan berat umbi per umbi, dimana perlakuan terbaik terdapat pada kombinasi perlakuan pemberian Hormax $3 \mathrm{ml} / \mathrm{liter}$ air dan NPK Mutiara (16:16:16) 6,3 g/tanaman (H2N2) yaitu $300.00 \mathrm{~g}$, tidak berbeda nyata dengan perlakuan $\mathrm{H} 3 \mathrm{~N} 2, \mathrm{H} 2 \mathrm{~N} 3$ dan berbeda nyata dengan perlakuan lainya

Perlakuan terbaik berat umbi per umbi (H2N2), hal ini di sebabkan karena pemberian Hormax dan pupuk NPK Mutiara (16:16:16) hormon mampu mempercepat pertumbuhan tanaman, memperbanyak dan mempercepat umbi atau rimpang, mengurangi kerontokan bunga, buah. dan meningkatkan ketersediaan unsur hara yang baik dan seimbang menyebabkan pertumbuhan akar tanaman maksimal dan fotositeis serta translokasi asimilat hasil fotosintesis inilah proses pengisian dan pembesaran umbi pada tanaman ubi jalar berlangsung dengan baik, sehingga ukuran umbi menjadi besar dan secara tidak lansung berat umbi menjadi tinggi.

Data pada Tabel 3 memperlihatkan bahwa pengaruh utama pemberian Hormax berpengaruh nyata terhadap berat umbi per plot, 
dimana perlakuan $\mathrm{H} 2$ ( $3 \mathrm{ml} /$ liter air) memiliki berat umbi per plot mencapai 2,56 g,berbeda nyata dengan perlakuan lainya. Ini disebabkan pada perlakuan $\mathrm{H} 2$ merupakan dosis yang tepat sehingga mempercepat pertumbuhan umbi atau rimpang pada tanaman ubi jalar.

Secara umum manfaat hormon organik bagi tanaman untuk mempercepat pertumbuhan tanaman, akar, memperbanyak dan mempercepat umbi atau rimpang, mengurangi kerontokan bunga dan buah. Dibandingkan hormon kimia, hormon organik mempunyaikisaran dosis lebih besar sehingga jika kelebihan tidak membahayakan tanaman, mudah terurai oleh alam dan aman bagi manusia dan lingkungan (Anonimus, 2014).

Data pada Tabel 3 memperlihatkan bahwa pengaruh utama pemberian NPK Mutiara (16:16:16) berpengaruh nyata terhadap berat umbi per plot, dimana perlakuan N2 memiliki berat umbi per plot mencapai $258,68 \mathrm{~g}$. Perlakuan N2 berbeda nyata dengan perlakuan lainya. Ini di sebabkan pada perlakuan N2 mampu memberikan unsur hara yang cukup sehingga perkembangan umbi pada tanaman ubi jalar optimal.

Rani dan Fenti (2001) mengemukakan bahwa unsur hara $\mathrm{N}, \mathrm{P}, \mathrm{K}$ dan air saling berkaitan dalam mempengaruhi perkembangan umbi tanaman. Keterikatan tersebut yaitu dalam merangsang peningkatan fotosintesis agar pembentukan dan sintesis protein, karbohidrat menjadi maksimal dan ternsportasi serta diferensiasi sel yamg menyebabkan penyimpanan cadangan makanan berupa pati didalam umbi menjadi maksimal. Hal ini menyebabkan perkembangan umbi menjadi maksimal dan secara tidak langsung berat umbi per umbi akan meningkat. Selain itu juga disebabkan karena tingkat perbaikan fisik, kimia dan biologi tanah tidak terjadi dengan optimal sehingga agregat tanah, ketersediaan hara dan air serta penguraian bahan organik tanah rendah dan tidak sesuai dengan kebutuhan tanaman.

Menurut Guwet (2009), untuk meningatkan bobot umbi per umbi tanaman ubi jalar yang menghasilkan, perlu dilakukan penambahan unsur hara melalui pemupukan pada dosis maksimum sehingga jumlah karbohidrat yang dihasilkan jumlahnya lebih besar dari jumlah umbi. Namun berat umbi dapat saja optimal jika terjadi keseimbangan jumlah umbi dan karbohidrat yang dihasilkan tanaman melalui dosis pemupukan optimum.

\section{Berat Umbi Per Tanaman (g)}

Hasil pengamatan Berat Umbi Per Tanaman pada tanaman ubi jalar, setelah dilakukan analisis sidik ragam menunjukkan bahwa interaksi perlakuan Hormax dan NPK Mutiara (16:16:16) tidak berpengaruh nyata, namun perlakuan utama Hormax memberikan pengaruh nyata dan NPK Mutiara (16:16:16) memberikan pengaruh nyata. Rerata hasil pengamatan indeks panen setelah di uji lanjut BNJ pada taraf 5\% dapat dilihat pada Tabel 4 .

Tabel 4. Rerata berat umbi per tanaman pembaerian Hormax dan NPK Mutiara 16:16:16 (g)

\begin{tabular}{|c|c|c|c|c|c|}
\hline \multirow{2}{*}{$\begin{array}{l}\text { Pemberian Hormax } \\
\text { (ml/liter air) }\end{array}$} & \multicolumn{4}{|c|}{ Pupuk NPK Mutiara 16:16:16 (g/tanaman) } & \multirow{2}{*}{ Rerata } \\
\hline & N0 ( 0) & N1 $(3,15)$ & $\mathrm{N} 2(6,3)$ & $\mathrm{N} 3(9,45)$ & \\
\hline H0 (0) & $152,42 n$ & $222,00 \mathrm{mn}$ & $403,53 \mathrm{ijk}$ & $280,97 \mathrm{~lm}$ & $264,73 \mathrm{~d}$ \\
\hline H1 (1) & $195,00 \mathrm{n}$ & $525,20 \mathrm{gh}$ & $762,97 \mathrm{a}-\mathrm{d}$ & $460,25 \mathrm{~g}-\mathrm{j}$ & $485,85 \mathrm{c}$ \\
\hline $\mathrm{H} 2(3)$ & 301,171 & 706,67 cde & $818,33 \mathrm{a}$ & $785,23 \mathrm{abc}$ & $652,85 \mathrm{a}$ \\
\hline $\mathrm{H} 3(5)$ & 480,00 ghi & $534,53 \mathrm{~g}$ & $798,57 \mathrm{ab}$ & $652,85 \mathrm{ef}$ & $616,49 \mathrm{~b}$ \\
\hline Rerata & $282,15 \mathrm{~d}$ & $497,10 \mathrm{c}$ & $695,85 \mathrm{a}$ & $544,83 \mathrm{~b}$ & \\
\hline $\mathrm{KK}=5,14 \%$ & \multicolumn{2}{|c|}{ BNJ $\mathrm{HN}=79.03$} & $\operatorname{dan} \mathrm{N}=28,79$ & & \\
\hline
\end{tabular}

Angka-angka pada baris kolom yang diikuti oleh huruf kecil yang sama tidak berbeda nyata berdasrkan Uji BNJ taraf 5\%.

Data pada Tabel 4 memperlihatkan bahwa secara interaksi pemberian Hormax dan NPK Mutiara (16:16:16) berpengaruh terhadap pengamatan berat umbi pertanaman, dimana perlakuan terbaik terdapat pada pemberian Hormax $3 \mathrm{ml} /$ liter air (H2N2) dengan berat umbi pertanaman $818,33 \mathrm{~g}$ tidak berbeda nyata dengan perlakuan H3N2, H2N3, H1N2. berbeda nyata dengan lainya.

Perlakuan terbaik Berat umbi pertanaman yang dihasilkan oleh perlakuan H2N2,Jika dikonversikan kedalam luas lahan 1 ha, berat 
umbi per tanaman yang dihasilkan pada perlakuan $\mathrm{H} 2 \mathrm{~N} 2$ lebih tinggi dari deskripsi varietas ubi jalar yaitu $818,33 \mathrm{~g} /$ tanaman atau setara dengan 38,96 ton per hektar, sementara rerata hasil produksi varietas ubi jalar yaitu 35 ton per hektar.

Data pada Tabel 4 memperlihatkan bahwa pengaruh utama pemberian Hormax berpengaruh nayata terhadap berat umbi per tanaman, dimana perlakuan perlakuan $\mathrm{H} 2$ (3 $\mathrm{ml} /$ liter air) memiliki berat umbi per tanaman mencapai $652,85 \mathrm{~g}$. berbeda nyata dengan perlakuan lainya. Hal ini disebabkan pemberian Hormax pada $3 \mathrm{ml} /$ liter air sesuai dengan dosis yang tepat bagi tanaman. Sehingga dapat merangsang pembesaran pada rimpang dan umbi pada tanaman umbi-umbian.

Data pada Tabel 4 memperlihatkan bahwa pengaruh utama pemberian pupuk NPK Mutiara (16:16:16) berpengaruh nyata terhadap berat umbi pertanaman, dimana perlakuan (N2) $6,3 \mathrm{~g} /$ tanaman memiliki berat umbi per tanaman mencapai 695,85 g berbeda nyata dengan perlakuan lainya. Hal ini disebabkan pemberian pupuk NPK Mutiara (16:16:16) pada 6,3 $\mathrm{ml} /$ liter air sesuai dengan dosis yang tepat bagi tanaman.

Widodo dan Rahayuningsih (2009), menyebutkan bahwa faktor penyebab belum optimalnya produktivitas ubi jalar di lahan petani secara umum adalah teknik budidaya yang masih sederhana dan pemupukan dosis rendah, atau bahkan tanpa pemupukan. Wilayah nonsentra yang produktivitasnya lebih rendah dari $10 \mathrm{t} / \mathrm{ha}$, secara umum merupakan wilayah pertanian yang penggunaan pupuk untuk seluruh jenis tanaman masih rendah. Kenyataan ini menunjukan adanya peluang peningkatan produksi ubi jalar secara nasional.

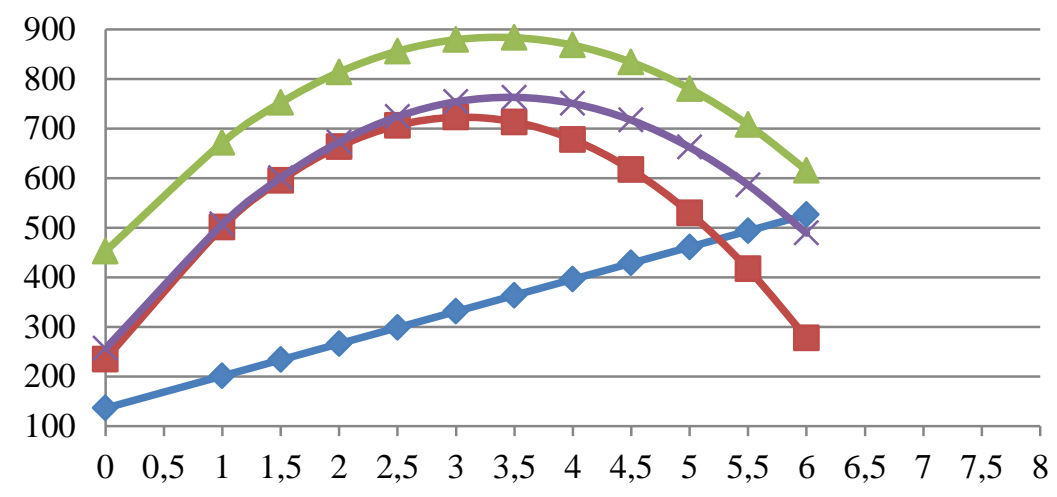

\section{Konsentrasi Hormax}

$$
\begin{aligned}
& -\mathrm{N} 0, \hat{\mathrm{Y}}=135,84+65,03 \mathrm{X} 0 \mathrm{X} 2, \mathrm{R} 2=94 \% \\
& -\mathrm{N} 1, \hat{\mathrm{Y}}=234,84+318,1 \mathrm{X}-51,825 \mathrm{X} 2, \mathrm{R} 2=98 \%, \mathrm{Xmax}=3,07, \mathrm{Ymax}=722,97 \\
& -\mathrm{N} 2, \hat{\mathrm{Y}}=452,35+257,46 \mathrm{X}-38,376 \mathrm{X} 2, \mathrm{R} 2=86 \%, \mathrm{Xmax}=3,35, \mathrm{Ymax}=884,18 \\
& \times \mathrm{N} 3, \hat{\mathrm{Y}}=256,09+293,21 \mathrm{X}-42,398 \mathrm{X} 2, \mathrm{R} 2=96 \%, \mathrm{Xmax}=3,46, \mathrm{Ymax}=763,03
\end{aligned}
$$

Gambar 1. Kurva hubungan konsentrasi Hormax (ml/l air) terhadap Berat Umbi Per Tanaman Ubi Jalar pada konsentrasi: H0 (kontrol), H1 (1 ml/1 air), H2 (3 ml/l air), H3 (5ml/l air).

Dari Gambar 1 dapat dijelaskan berdasarkan persamaan garis duga pemberian Hormax 3,07 dapat tercapai berat umbi per tanaman sebesar 722,97 gram, sedangkan pemberian Hormax 3,35 dapat tercapai berat umbi per tanaman 884,18 gram, pemberian Hormax 3,46 dapat tercapainya berat umbi per tanaman sebesar 763,03 gram.

Dari Gambar 1 dapat dijelaskan bahwa dengan pemberian konsentrasi H0 menghasilkan koefesien determinasi $\left(\mathrm{R}^{2}=94 \%\right)$ artinya $94 \%$ berat umbi pertanaman dipengaruhi oleh hormax, sedangkan $\mathrm{H} 1$ menghasilkan koefesien determinasi $\left(\mathrm{R}^{2}=98\right.$ $\%$ ) artinya $98 \%$ berat umbi per tanaman dipengaruhi hormax, $\mathrm{H} 2$ menghasilkan koefesien determinasi $\left(\mathrm{R}^{2}=86 \%\right)$, artinya $86 \%$ berat umbi per tanaman dipengaruhi hormax, dan H3 menghasilkan koefesien determinasi $\left(\mathrm{R}^{2}=96 \%\right)$, artinya $96 \%$ berat umbi per tanaman dipengaruhi hormax. 


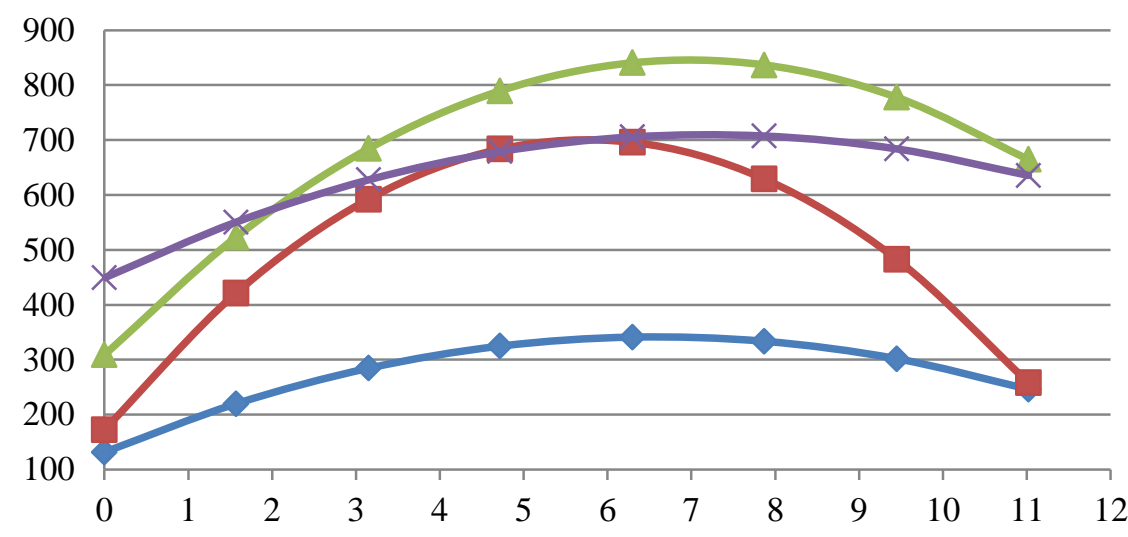

Dosis pupuk NPK Mutiara (16:16:16)

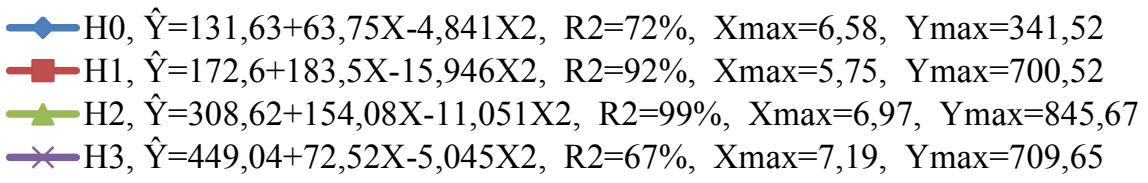

Gambar 2. Kurva hubungan dosisNPK Mutiara 16:16:16(g/tanaman) terhadap Berat Umbi Per Tanaman Ubi Jalarpada dosis: N0 (kontrol), N1 (3,15 g/tanaman), N2 (6,3 g/tanaman), N3 (9,45 g/tanaman).

Dari Gambar 2 dapat dijelaskan, berdasarkan persamaan garis duga dapat dilihat pemberian dosis NPK Mutiara (16:16:16)yaitu tanpa pemberian NPK Mutiara (16:16:16) yaitu 6,58 dapat tercapainya berat buah per tanaman ubi jalar341,52 gram. Sedangkan dosis NPK Mutiara (16:16:16)3,15 g/tanaman yaitu 5,75 dapat tercapainya berat buah pertanaman ubi jalar700,52 gram. Sedangkan pada dosis NPK Mutiara (16:16:16)6,3 g/tanaman yaitu 6,97 dapat tercapainya berat buah per tanaman ubi jalar sebesar 845,67 gram.dan dosis NPK Mutiara (16:16:16)9,45 g/tanaman yaitu 7,19 dapat tercapainya berat buah per tanaman ubi jalar709,65gram.

Dari Gambar 2 dapat dijelaskan bahwa dengan pemberian dosis N0 menghasilkan koefesien determinasi $\left(\mathrm{R}^{2}=72 \%\right)$ artinya $72 \%$ berat umbi pertanaman dipengaruhi oleh NPK Mutiara (16:16:16), sedangkan $\mathrm{N} 1$ menghasilkan koefesien determinasi $\left(\mathrm{R}^{2}=92\right.$ $\%$ ) artinya $92 \%$ berat buah per tanaman NPK Mutiara (16:16:16), N2 menghasilkan koefesien determinasi $\left(\mathrm{R}^{2}=99 \%\right)$, artinya $99 \%$ berat umbi per tanaman dipengaruhi NPK Mutiara (16:16:16), dan N3 menghasilkan koefesien determinasi $\left(\mathrm{R}^{2}=67 \%\right)$, artinya $67 \%$ berat umbi per tanaman dipengaruhi NPK Mutiara (16:16:16).

\section{Berat Berangkasan basah (g)}

Hasil pengamatan berat umbi per umbi pada tanaman ubi jalar, setelah dilakukan sidik ragam menunjukkan bahwa interaksi perlakuan Pupuk Hormax dan NPK Mutiara 16:16:16 menberikan pengaruh yang nyata terhadap jumlah umbi pertanaman. Rerata hasil pengamatan jumlah per tanaman setelah di uji lanjut BNJ pada taraf 5\% dapat dilihat pada Tabel 5.

Data pada Tabel 5 Memperlihatkan bahwa interaksi pemberian Hormax dan NPK Mutiara (16:16:16) menberikan pengaruh terhadap berat berangkasan basah tanaman ubi jalar, dimana kombinasi perlakuan terbaik terdapat pada pemberian Hormax $3 \mathrm{ml} /$ liter air dan NPK Mutiara (16:16:16) 6,3 g/tanaman $(\mathrm{H} 2 \mathrm{~N} 2)$ dengan bearat berangkasan mencapai $958,43 \mathrm{~g}$, tidak berbeda nyata dengan perlakuan (H3N2) berdeda nyata dengan perlakuan lainya.

Perlakuan terbaik berat barangkasan basah tanaman ubi jalar yaitu (H2N2) 958,43 g. Hal ini di duga karena kombinasi Hormax dan 
NPK Mutiara (16:16:16) mampu memberikan pertumbuhan pada tanaman ubi jalar dan pemberian pupuk yang sesuai dengan dosis, sehingga pertumbuhan pada tanaman ubi jalar optimal.

Tabel 5. Rerata berat berangkasan basah pembaerian Hormax dan NPK Mutiara 16:16:16(g)

\begin{tabular}{cccccc}
\hline \multirow{2}{*}{$\begin{array}{c}\text { Pemberian Hormax } \\
(\mathrm{ml} / \text { liter air })\end{array}$} & \multicolumn{3}{c}{ Pupuk NPK Mutiara 16:16:16 (g/tanaman) } & Rerata \\
\cline { 2 - 5 } H0 $0(0)$ & $298,77 \mathrm{k}$ & $316,67 \mathrm{jjk}$ & $366,67 \mathrm{f}-\mathrm{k}$ & $333,33 \mathrm{~g}-\mathrm{k}$ & $328,86 \mathrm{~d}$ \\
H1 (1) & $310,57 \mathrm{jk}$ & $416,67 \mathrm{fgh}$ & $808,50 \mathrm{bcd}$ & $382,10 \mathrm{f}-\mathrm{j}$ & $479,46 \mathrm{c}$ \\
H2 (3) & $364,30 \mathrm{~g}-\mathrm{k}$ & $779,83 \mathrm{de}$ & $958,43 \mathrm{a}$ & $834,17 \mathrm{bc}$ & $734,18 \mathrm{a}$ \\
H3 (5) & $405,17 \mathrm{f}-\mathrm{i}$ & $420,00 \mathrm{fg}$ & $894,10 \mathrm{ab}$ & $435,00 \mathrm{f}$ & $538,57 \mathrm{~b}$ \\
\hline Rerata & $344,70 \mathrm{~d}$ & $483,29 \mathrm{bc}$ & $756,93 \mathrm{a}$ & $496,15 \mathrm{~b}$ & \\
\hline KK $=6,08 \%$ & \multicolumn{4}{c}{ BNJ HN $=96,17$} & \multicolumn{3}{c}{ BNJ H dan N $=35,04$} & \\
\hline
\end{tabular}

Data pada Tabel 5 Memperlihatkan bahwa pengaruh utama pemberian Hormax berpengaruh nyata terhadap berat berangkasan basah, dimana perlakuan (H2) $3 \mathrm{ml} / \mathrm{liter}$ air memiliki berat barangkasan basah 734,18 g. Berbeda nyata dengan perlakuan lainya. Hal ini disebabkan dengan pemberian Hormax mampu memperbaiki dan membantu pertumbuhan fisiologi tanaman ubi jalar.

Menurut Irwanto (2001), dengan penambahan sitokinin dan giberelin eksogen maka terjadi peningkatan kabdungan sitokinin dan giberelin ditanaman (tajuk) dan akar meningkatkan jumlah sel oleh hormon sitokinin dan ukuran sel oleh hormon giberelin yang bersama-sama dengan hasil fotosintat yang meningkatkan diawal penanaman akan mempercepat proses pertumbuhan vegetatif tanaman termasuk pertumbuhan tunas-tunas baru selain itu juga mengatasi kekerdilan tanaman.

Hasil fotosintesa yang meningkat akan meningkatkan berat kering tanaman. Hal ini sesuai dengan pernyataan Anonimus (2009), bahwa pemberian Hormax dengan dosis tepat akan memberikan pengaruh terhadap pertumbuhan dan perkembangan tanaman terutama terlihat pada daun yang menjadi lebih lebar dan lebat dari biasanya.

Data pada Tabel 5 memperlihatkan bahwa pengaruh utama pemberian pupuk NPK Mutiara (16:16:16) berpengaruh nyata terhadap berat umbi pertanaman, dimana perlakuan N2 (6,3 g/tanaman) memiliki berat berangkasan basah mencapai 756,93 g, berbeda nyata dengan perlakuan lainya. Hal ini disebabkan pemberian pupuk NPK Mutiara (16:16:16) pada 6,3 $\mathrm{ml} /$ liter air sesuai dengan dosis yang tepat bagi tanaman, karena dapat memberikan asupan unsur hara yang optimal sehingga dapat mempercepat perkembangan vegetatif pada tanaman ubi jalar.

Marsono dan Sigit (2002), mengemukakan bahwa kekurangan unsur hara nitrogen pada tanaman dapat menyebabkan pertumbuhan tanaman lambat atau kecil, dan hijau kekuningan, daun sempit, pendek dan tegak daun tua cepat menguning dan mati. Sedangkan kekurangan unsur hara fosfor pada tanaman dapat menyebabkan daun berubah menjadi warna tua atau tampak kemerahan, tepi daun cabang dan batang bewarna ungu lalu berubah menjadi kuning, buah kecil dan lekas matang. Selain unsur fosfor, unsur kalium pada tanaman juga berperan penting dalam membantu pembentukan protein dan karbohidrat, memperkuat jaringan tanaman, membentuk anti bodi tanaman terhadap penyakit serta kekeringan dan mengaktifkan kerja beberapa enzim serta memacu translokasi karbohidrat daridaun keorgan tanaman yang lain.

\section{Indeks Panen}

Hasil pengamatan indeks panen pada tanaman ubi jalar, setelah dilakukan analisis sidik ragam menunjukkan bahwa interaksi perlakuan Hormax dan NPK Mutiara (16:16:16) tidak berpengaruh nyata, namun perlakuan utama Hormax memberikan pengaruh nyata dan NPK Mutiara (16:16:16) memberikan pengaruh nyata. Rerata hasil pengamatan indeks panen setelah di uji lanjut BNJ pada taraf 5\% dapat dilihat pada Tabel 6 . 
Data pada Tabel 6 memperlihatkan bahwa pengaruh utama pemberian Hormax berpengaruh nyata terhadap indeks panen, dimana perlakuan $\mathrm{H} 2$ ( $3 \mathrm{ml} /$ liter air) memiliki indeks panen tertinggi yakni $0,44 \mathrm{~g}$ tidak berbeda nyata dengan perlakuan $\mathrm{H} 3, \mathrm{H} 1$. Hal ini disebabkan dengan pemberian Hormax mampu meningkatkan pertumbuhan fisiologi dan umbi.

Tabel 6. Rerata indeks panen pembaerian Hormax dan NPK Mutiara 16:16:16 (g)

\begin{tabular}{cccccc}
\hline \multirow{2}{*}{$\begin{array}{c}\text { Pemberian Hormax } \\
(\mathrm{m} 1 / \text { liter air })\end{array}$} & \multicolumn{3}{c}{ Pupuk NPK Mutiara 16:16:16 (g/tanaman) } & \multirow{2}{*}{ Rerata } \\
\cline { 2 - 5 } H0 $(0)$ & 0,34 & 0,35 & 0,37 & 0,36 & $0,36 \mathrm{~b}$ \\
H1 (1) & 0,35 & 0,41 & 0,45 & 0,38 & $0,40 \mathrm{a}$ \\
H2 (3) & 0,40 & 0,42 & 0,47 & 0,43 & $0,44 \mathrm{a}$ \\
H3 (5) & 0,37 & 0,44 & 0,42 & 0,46 & $0,43 \mathrm{a}$ \\
\hline Rerata & $0,37 \mathrm{~b}$ & $0,41 \mathrm{a}$ & $0,43 \mathrm{a}$ & $0,41 \mathrm{a}$ & \\
\hline KK = 8,21 \% & BNJ H dan N = 0,04 & & \\
\hline Angka-angka pada baris kolom yang diikuti oleh huruf kecil yang sama tidak berbeda nyata berdasrkan Uji BNJ taraf 5\%.
\end{tabular}

Hormon yang sering digunakan adalah auksin dan sitokinin. Salah satu digolongkan auksin sintetik adalah 2,4 Dichlorophenoxyacetic (2,4-D). Peran fisiologis auksin adalah pemanjangan sel yang berakibat pemanjangan batang. Fungsi dari auksin untuk mempercepat pertumbuhan akar, batang, perkecambahan, membantu proses pembelahan sel, mempercepat pemasakan buah, menurangi jumlah biji dalam buah. Golongan sitokinin alami dapat diperoleh dari air kelapa. Sitonin berperan merangsang pembelahan sel, merangsang pembentukan tunas batang naupun pada kalus, menghambat efek dominansi apikal (Nurhayati, 2008).

Data pada Tabel 6 memperlihatkan bahwa pengaruh utama pemberian NPK Mutiara (16:16:16) berpengaruh nyata terhadap indeks panen, dimana perlakuan N2 $\quad(6,3$ $\mathrm{g} /$ tanaman) memiliki indeks panen tertinggi 0,43 g. Tidak Berbeda nyata dengan perlakuan H3, H1. Hal ini disebabkan adanya unsur fospor dan kalium pada NPK Mutiara (16:16:16) berperan penting dalam perkembangan tumbuhan sehingga mampu meningkatkan pertumbuhan tanaman ubi jalar dengan optmal.

Marsono dan Sigit (2002), mengemukakan bahwa kekurangan unsur hara nitrogen pada tanaman dapat menyebabkan pertumbuhan tanaman lambat atau kecil, dan hijau kekuningan, daun sempit, pendek dan tegak daun tua cepat menguning dan mati. Sedangkan kekurangan unsur hara fosfor pada tanaman dapat menyebabkan daun berubah menjadi warna tua atau tampak kemerahan, tepi daun cabang dan batang bewarna ungu lalu berubah menjadi kuning, buah kecil dan lekas matang. Selain unsur fosfor, unsur kalium pada tanaman juga berperan penting dalam membantu pembentukan protein dan karbohidrat, memperkuat jaringan tanaman, membentuk anti bodi tanaman terhadap penyakit serta kekeringan dan mengaktifkan kerja beberapa enzim serta memacu translokasi karbohidrat daridaun keorgan tanaman yang lain.

Arifin dan Nur Hayati (2005) mengemukakan bahwa untuk mendapatkan pertumbuhan tanaman yang baik, unsur hara esensial harus mencukupi, bila tanaman kekurungan unsur hara tanaman tanaman tidak akan melakukan fungsi fisiologisnya dengan baik dan akan berpengaruh terhadap tanaman yang dibudidayakan. Agustina (2004) mengemukakan bahwa unsur nitrogen, fosgor dan kalium sangat penting bagi tanaman, termasuk bagian yang berhubungan dengan perkembangan generatif yang menyebebkan metabolisme dalam tubuh tanaman menjadi lebih baik.

\section{KESIMPULAN DAN SARAN}

\section{Kesimpulan}

Dari hasil penelitian yang telah dilaksanakan dapat diambil kesimpulan bahwa:

1. Interaksi berbagai konsentrasi hormax dan pupuk NPK Mutiara (16:16:16) hanya berpengaruh nyata terhadap jumlah umbi per tanaman, berat umbi per plot, berat umbi per umbi, berat berangkasan basah, 
indeks panen. Perlakuan terbaik adalah konsentrasi hormax $3 \mathrm{ml} / \mathrm{liter}$ air dan pupuk NPK Mutiara (16:16:16) sebanyak 6,3 g/tanaman (H2N2).

2. Pengaruh utama konsentrasi hormax berpengaruh nyata terhadap jumlah umbi per tanaman, berat umbi per plot, berat umbi per umbi, berat umbi per tanaman, berat berangkasan basah, indeks panen. Perlakuan terbaik adalah konsentrasi hormax 3 ml/liter air (H2).

3. Pengaruh utama dosis pupuk NPK Mutiara (16:16:16) berpengaruh nyata terhadap jumlah umbi per tanaman, berat umbi per plot, berat umbi per umbi, berat buah per umbi, berat berangkasan basah, indeks panen. Perlakuan terbaik adalah dosis pupuk NPK Mutiara (16:16:16) sebanyak 6,3 g/tanaman (N2).

\section{Saran}

Berdasarkan dari hasil penelitian, aplikasi hormax dan pupuk NPK Mutiara (16:16:16) terhadap tanaman ubi jalar disarankan perlu dilakukan penelitian lanjutan sampai umur tanaman 5-6 bulan dengan konsentrasi hormax 3 $\mathrm{ml} /$ liter air dan dosis pupuk NPK Mutiara (16:16:16) 6,3 g/tanaman untuk mengurangi penggunaan pupuk anorganik yang berlebihan.

\section{DAFTAR PUSTAKA}

Adrianto, T.T dan Indarto, N. 2004. Budidaya dan Analisis Usaha Tani Ubi Jalar. Penebar Swadaya. Jakarta.

Anonimus, 2009. Teknik Budidaya Tanaman Kunyit Putih. Delta Media, Surakarta. a.2014.Hormon dan tanaman http://a.2014eshaflora.blogspot.com/2011 /.../hormon-dan-pertumbuhantanaman.htm.diakses28September 2016. b.2014. Manfaat dan Keunggulan Penggunaan Hormon Organik. www://http.Hormon Organik. Blogspot.com. diakses 28 september 2016..

Andrianto, T.T dan Indarto. N. 2004 Budidaya dan Analisis Usaha Tani Ubi Jalar. Penebar Swadaya. Jakarta.

Arifin dan Nur Hayati. 2005. Pemeliharaan Tanaman. Penebar Swadaya. Jakarta.
Guwet, H. W. 1992. Karakteristik Ukuran Umbi dan Bentuk Umbi Plasma Nutfah Ubi Jalar. Balai Plasma Nutfah. Badan Penelitian Bioteknologi dan Sumber Daya Genetik. 9 (2) : 7-15.

Hanafi, A.K. 2005. Dasar-dasar Ilmu Tanah. Rajagrafindo Persada. Jakarta.

Indrawati, 2014. Respon Tanaman Ubi Jalar (Ipomea batatas L.) Terhadap pemberian Kompos dan Dosis NPK Mutiara 16:16:16. Skripsi Fakultas Pertanian Universitas Islam Riau.

Irwanto, 2001. Pengaruh Hormon IBA (indole butyric acid) terhadap Persen jadi Stek Pucuk Meranti Putih (Shorea montigenasp.). Skripsi Fakultas Pertanian Universitas Pattimura. Ambon.

Marsono dan Sigit, P. 2002. Pupuk akar jenis dan Aplikasinya. Penebar swadaya: Jakarta.

Nugroho, Y.A. 2004. Pertumbuhan dan Hasil Tanaman Selada (Lactuca setivaL.) .akibat Pemberian Bahan Organik dari Biomassa Tanaman dan Pupuk Kandang yang Ditanam pada Masa Tanam Kedua. Laporan Penelitian. LPPM Universitas Widyagama, Malang.

Nurahmi, E. 2010. Pertumbuhan dan Hasil Kubis Bunga Akibat Pemberian Pupuk Organik Cair nasa dan zat pengatur tumbuh Hormonik. Jurnal Agrista.14 (3) : 08-83.

Nurhayati, 2008. Pengaruh Pupuk Kalium Pada Ketahanan Kacang Tanah Terhadap Bercak Daun Cerospra. Graha Ilmu. Yogyakarta.

Rani, dan Fenti, S. 2001. Pengaruh Pemberian NPK dan Berbagai Pupuk OrganikTerhadap Pertumbuhan dan Hasil Bawang Merah. Jurnal Hortikultura.21(1): 10-18.

Ralahalu, 2013. Respon Tanaman cabe besar (capsicum annuитL.). terhadap pemberian hormon organik. Jurnal Agrologia. 2 (4) : 95-100.

Rahayuningsih, st. A,. 2002. Keragaman klonklon ubi jalar Harapan ubi jalar di tiga daerah penhhasil ubi jalar. Jurnal Pertanian Mapeta. 8 (2) : 103-110

Widodo, Y. dan Rahayuningsih, S.A. 2009. Teknologi budidaya ubi jalar mendukung ketahanan pangan danusaha agro industri. Bul. Palawija No.17:25-32. 
